metabolism of the resting individual is proportional to the surface area of his body. In 1883-84 he made accurate measurements of the calorific value of various foodstuffs, and his figures are still generally used throughout the world in calculating the energy values of diets. In 1885 he was appointed to the newly created chair of hygiene at Marburg, where four years later he constructed, mainly with his own hands, the first accurate self-registering respiration calorimeter for use with dogs. A similar apparatus was later made for man by W. O. Atwater and E. B. Rosa. In 1891 Rubner succeeded Robert Koch as professor and director of the Institute of Hygiene at Berlin, and in 1909, at T. W. Engelmann's death, he became professor of physiology. He retired in 1922, and died on April 27, 1932, aged seventy-eight. Throughout his career he viewed metabolism from the point of view of energy, visualizing molecular. oxidative cleavage as responsible for fresh supplies of energy to make up for the unpreventable loss occurring in all living things.

\section{Recent Greek Earthquakes}

A SERIES of earthquakes in Greece has recently caused the deaths of twenty-seven people, injury to about two hundred others and devastation over wide

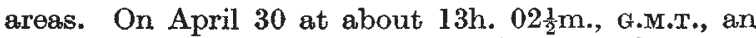
earthquake with an epicentre near lat. $39 \cdot 3^{\circ} \mathrm{N}$., long. $22 \cdot 1^{\circ}$ E., near Sophades was felt over an area of 1,150 square miles. It was recorded at Stuttgart at 13h. $05 \mathrm{~m}$. $45 \cdot 5 \mathrm{~s}$. , G.M.T., at Edinburgh at $13 \mathrm{~h} .07 \mathrm{~m}$. 48s., G.M.T., and at most European observatories. Forty-eight observatories, including some in places as far from the epicentre as western America, India and Pakistan, immediately sent their observations to the United States Coast and Geodetic Survey. The instrumental magnitude appears to have been near 7. In the epicentral area at Sophades and Pharsala some 60 per cent of the buildings were down, while at Karditza some 20 per cent of the buildings were destroyed. Minor damage was caused at Volo, Lamia, Larissa and Trikkala. The railway was damaged at Dhomokos. Altogether, about twelve hundred houses were estimated to have been made uninhabitable and ten thousand people rendered homeless. The damage is estimated at $£ 2$ million. Aftershocks have been frequent, and some have been strong ; those on May 1 (five strong tremors), May 4 (one strong tremor), May 5 (five strong tremors) with property damage at Soupi, and May 12 (two strong tremors) have all been felt. Tremors have also been reported from Tropaia, Patras and Tripolis, and also from south-west Greece and the Peloponnese. On May 12 one of the casualties mentioned above was caused at Aspraspitia near Pirgos, and property damage was occasioned at the time there and also at Xirokambos.

New Gallery at the Science Museum, London: Gas Manufacture and Distribution

A NEW gallery devoted to the history of gas manufacture, its distribution and its by-products up to the present day, has been set up in the Science Museum, London, and was opened on May 25 by the Lord President of the Council, the Marquess of Salisbury. The display occupies a gallery of some five thousand square feet in a newly finished wing of the Museum and has been organized by a committee of the Institution of Gas Engineers, upon which the Gas Council, various manufacturing interests and the Science Museum are represented, the whole being under the chairmanship of Mr. F. M. Birks, deputy chairman of the North Thames Gas Board. The gallery illustrates not only the beginning of the making of gas, first for lighting and then for heating, and its industrial uses, but also the later uses of the many by-products of coal created through the gasmaking process. A series of realistic dioramas shows some of the early experimenters at work, followed by representative retort houses at various dates up to the present day. A cyclorama running the whole length of the gallery depicts London's gas-lighted streets in 1812, the gas-lit scene at a Mansion House ball as long ago as 1830, private house lighting thirty years ago, and the advent of the incandescent mantle sixty-four years ago. Models representing gas-works in 1890 and 1950 show the progress of the machinery for gas-making. Illuminated panels, operated by push-buttons, show by animated diagrams the various stages in the extraction of gas from coal, how it is distributed to the consumer, and what happens to the by-products that remain. An illustrated brochure is available.

\section{Council for the Preservation of Rural Wales}

IN its annual report for 1952-53, the Council for the Preservation of Rural Wales directs attention to the measures which have been taken during the twenty-five years of its existence to protect the natural countryside from despoliation and disfiguration. Among these are the substantial advances which have been made in town and country planning. Roadside ribbon development, for example, has been checked, while the principle of restoration after mineral extraction has been accepted, as well as the long-term assessment of land required for this purpose. The siting, layout and design of local-authority housing has been much improved and ugly outdoor advertising has become the subject of control. The Forestry Commission is no longer solely concerned with State forests, the proper maintenance of privately owned woodlands and the control of felling of privately owned trees now falling within its purview. The passing of the National Parks and Access to the Countryside Acts in 1949 and the establishment of the National Parks Commission and the Nature Conservancy were valuable developments, while the importance of preserving buildings has been recognized by the establishment of the Historic Buildings Councils. The Rivers (Prevention of Pollution) Act of 1951 has also led to much more effective control. The Council is less happy, however, about developments which have taken place since the electrical industry was nationalized, and a problem which has assumed considerable proportion is the rapid increase in caravan sites. The report also contains details of specific measures taken during the past year to protect the natural amenities of Wales.

\section{Scientific and Technical Periodicals of South East Asia}

THE second edition of the "List of Scientific and Technical Periodicals of South East Asia" (pp. 233. Manila: South East Asia Science Co-operation Office, 1953) contains all the revisions and additions which the Office has been able to obtain from corre. spondents in Hong Kong, Japan, Indonesia, Macao, Malaya, North Borneo, the Philippines, Sarawak, Thailand and Vietnam; the entry for Japan is the first to appear in this list. But no revision of the list of Chinese periodicals has been possible, and the 